reduce death rates it is also within our power to limit birth rates". It quotes Vogt ${ }^{12}$, who believes that wherever the Food and Agriculture Organisation finds over-population, its conservation and food production programmes should include contraception programmes. He believes that food production may decrease rather than increase in many areas, and points out that, much more than is generally realized, the achievement of the 'four freedoms' depends on a fifth freedom : freedom from excessive numbers of children. Returning to the problem of tuberculosis in India, it is obvious that efforts will continue to be made to reduce the number of deaths from tuberculosis ; but it is difficult to see what real benefit this will produce in a country the population of which is increasing faster than its ability to produce or pur. chase food. In such circumstances the agricultural and veterinary sciences are of prime importance, and control of disease in man can only be of real benefit if it is combined with efforts to reduce the birth-rate : it is difficult to see what benefit is conferred by preventing ten thousand people from dying of tuber. eulosis this year in order that, in five years time, they may die of starvation.

- Stocks, P., Tubercle, 30, 50 (1949).

"Twort, F. W., and Ingram, G. L., "Johne's Disease" (London, 1913)

"Francis, J., Madinaveitia, J., Macturk, H. M., and Snow, G. A. Nature, 163, 365 (1949).

- Franeis, J. (to be published).

"Rich, A. R., "The Pathogenesis of Tuberculosis" (Baltimore, 1944).

- Franois, J., "Bovine Tuberculosis, including a Contrast with Human Tuberculosis" (London, 1947).

7 Pagel, W., in Kayne, Pagel and O'Shaughnessy's "Pulmonary Tur 1948).

. J., 102, 267 (1946).

- Francis, J. "Control of Infection with the Bovine Tubercle Bacillus", Lancet, i, Jan. 6 (1950).

"Francis, J.: "Tuberculosis : the Control of an Infectious Disease", Lancet, ii, 549 (1949).

$"$ Editorial, Lancet, ii, 613 (1949).

2 Vogt, W., "Road to Survival", 335 (London, 1949).

\section{CONFERENCE OF HOME UNIVERSITIES}

' HE fourth post-war Conference of the Universities of Great Britain and Northern Ireland was held at the Senate House, University of London, during December 16-17, and was attended by about a hundred delegates and guests.

At the first session, Sir Walter Moberly spoke on his book "The Crisis in the University" in the light of comments that have been made, particularly by Mr. Michael Oakeshott in the Cambridge Journal, and by a number of contributors in the November issue of the Universities Quarterly. Sir Walter emphasized that although his book was written with a Christian outlook, it is imperative from every point of view that the aims of the universities should be re. defined, and values re-considered. There are also, he said, a number of practical problems requiring decision, such as the communal relations of staff and students and the length of courses; but paramount is the need to ensure that students acquire at the university a philosophy of life and a certainty about ultimate loyalties. He did not, however, want any forced or unreal unity.

Sir Walter was criticized by a number of speakers, who did not share his Christian convictions or accept his disclaimer of any desire to use the universities for the exclusive inculcation of Christianity. Prof. L. J.
Russell (Birmingham) thought that the situation had been over-intellectualized, and that the decay of beliefs is due to the breakdown of the social institutions on which they rested. Many of the functions previously performed by the Church and also by the family have passed to other institutions. The associated beliefs have naturally been affected. What is required is a gradual building up of new beliefs firmly based on reality. He strongly supported Sir Walter's concept of the university as an open forum.

Prof. J. P. Kendall (Edinburgh) asked the Conference to compare the Catholic universities of Belgium with the free universities, in which no attempt is made to teach a philosophy of life. Prof. W. M. Calder (Edinburgh) considered that more important than a 'philosophy of life' is 'integrity of intellect'. Mr. Kenneth Urwin (Wales) was concerned with the ultimate results of Sir Walter's prescription, which he thought would be religious tests. Prof. T. M. Knox (St. Andrews) thought that Sir Walter wanted the universities to teach Christianity to those with whom Christian churches have failed. In his opinion, the universities should aim at turning out students who are incapable of not thinking for themselves. Speakers in support of Sir Walter tended to stress the danger of a vacuum. Sir John Maud (Permanent Secretary, Ministry of Education), who was a guest of the Conference, thought that the university should make the student hungry for a 'philosophy of life', but should not teach him any particular one. Prof. D. M. MacKinnon (Aberdeen) urged the necessity of studying the conditions favourable to the open mind and to objectivity. Intellectual honesty is essential if the universities are to survive. The danger of Marxism was emphasized by many speakers; since no voice was raised in its support, the Conference failed to achieve in this respect the open forum advocated by Sir Walter.

At the second session, "The General Education of Students" was the subject, and Prof. F. T. H. Fletcher (Liverpool), speaking as a representative of the Association of University Teachers, gave the opening address. This, he explained, was not a statement of official policy, although the Association of University Teachers has for long been interested in this problem, which is now being generally recognized as the dangers of specialization become more and more apparent. General education, that is, education outside the student's main study, is necessary for three reasons : to increase the value of the student to the community, to increase his effectiveness in his own specialization, and to liberate and enrich the human spirit.

Prof. Fletcher believed that the humanities have more to contribute to general education than the pure sciences and technologies, but Sir Lawrence Bragg (Cambridge) held that the education of the arts student in scientific method and in an elementary knowledge of science is the more urgent part of the problem. The science student is acquainted with the humanities by his previous education; the arts student usually knows little about science.

Prof. H. Hale Bellot (London) considered that the problem centres on the general education of the professor, and instanced as the correct approach to a solution the growing awareness by historians of other fields such as economics. Details of some interesting experiments in general education were given by a number of speakers, and a plea was made by Iord Chorley (Assuciation of University Teachers) 
for the publication of this information. Lord Lindsay of Birkar explained that the new University College of North Staffordshire is being established as an attempt to overcome the evils of specialization. He had been aware for many years that science and arts students were talking different languages and believed that the position is getting worse. At the new College, the four-year honours course which they would provide would begin with a first year in which general education and the correction of school over-specialization would be prominent.

The third session was concerned with "The Place of Technological Education in University Studies", and opened with an address by Sir Lawrence Bragg (Cambridge) and a paper (read in his absence) by Sir Edward Appleton (Edinburgh).

Sir Lawrence supported the founding of separate institutes of technology, on the lines of the Massachusetts Institute of Technology, but emphasized that he did not want to see all technological studies removed from the universities. Such institutes should be as autonomous as universities, should award their own degrees, and should differ from universities only in outlook. His attempt to draw a line between technological and pure scientific research was criticized by a number of speakers, notably Prof. J. B. Speakman (Leeds), who pointed out that his own university had grown from the Department of Textiles.

Sir Lawrence further maintained that while Great Britain has no need to fear comparison with any other in pure science, its record in technology is less satisfactory.

Sir Edward Appleton affirmed that the aim of the university is to produce engineering scientists, and of the technical college to produce engineers. He would support the establishment of one institute of technology, but was more concerned with the improvement of the existing university provision. He regretted the presence in universities of specialized technologies, and instanced glass, rubber, brewing and textiles.

Prof. Andrew Robertson (Bristol) thought that technological institutes such as the Massachusetts Institute of Technology are too little concerned with fundamental principles, and stated that there is criticism in America on this score. Prof. A. F. Burstall (Durham) supported the establishment of an institute of technology, but Sir John Hobhouse (Liverpool) and Prof. J. F. Baker (Cambridge) were in opposition, the latter declaring that it is the national attitude towards technology in the United States that has most to do with the American success in this field. Prof. J. P. Kendall (Edinburgh) thought that the virtue of the Massachusetts Institute of Technology lies in its lavish equipment and in the excellence of its postgraduate instruction. $\mathrm{He}$ was also inclined to oppose Sir Lawrence's proposition. In his opinion the fault in Great Britain lies in the arrangement of school education on the assumption that all the pupils would go to the university. Dr. P. Dunsheath (London) was among those who considered that it would be a mistake to remove technological studies from the university, and Sir Roderic Hill (London), by a statement of the actual proportions, rebutted the contention that technological students are in danger of swamping the universities. Principal J. C. Jones (director of education, Regent Street Polytechnic), a guest of the Conference, stressed the harmful effects of the social prestige of the university degree on the provision of courses by technical colleges, and in his reply to the discussion Sir Lawrence Bragg re-emphasized his desire to see new technological institutions, which would give their own degrees.

At the first session the chair was taken by Prof. Lillian Penson, vice-chancellor of the University of London, at the second by Prof. G. C. Field, pro-vicechancellor of the University of Bristol, and at the third by Sir Hector Hetherington, principal of the University of Glasgow, and chairman of the Committee of Vice-Chancellors and Principals, which convened the Conference.

\section{VOYAGE OF THE ROYAL} RESEARCH SHIP WILLIAM SCORESBY

$\mathrm{T}$

HE Royal Research Ship William Scoresby sailed on January 11 on a new voyage of ocean research in continuation of the work undertaken by the former Discovery Committee before the War. She will visit South African waters first, and then make observations across the Indian Ocean. The final months of the commission will be spent in study. ing whales in the West Australian region.

During the past twenty.five years the Discovery Committee has worked under the Colonial Office, and organised a series of expeditions for scientific research, mainly in the Southern Ocean and Antarctic seas, but sometimes also in subtropical and tropical waters. The work is generally referred to as the "Discovery Investigations", and has been concerned principally with deep-sea oceanography and especially with research on whales. The name "Discovery" was adopted because the work at sea began with Captain Scott's old ship, the Discovery (now lying off the Thames Embankment), but most of the investigations have been carried out with the Royal Researeh Ships Discovery $I I$ and William Scoresby. Since 1939 the ships have been on charter to the Ministry of Transport, but in 1949 the Discovery Investigations, together with the ships and scientific staff, were transferred to the Admiralty and now form part of the National Institute of Oceanography, of which Dr. G. E. R. Deacon is director.

The Institute as a whole covers a wider field, but in the next two years both ships will be engaged in the continuation of the Discovery Committee's programme under the general direction of Dr. N. A. Mackintosh, formerly director of research to the Committee. The Discovery II, which is the larger ship, is at present refitting for ocean research; her work will be largely in the Antarctic.

The present voyage of the William Scoresby is expected to last about ten months. She is a ship of 324 tons (gross) and has some of the features of a trawler and some of a whale catcher. She carries a commercial otter trawl, and there are deck engines and reels with some thousands of fathoms of wire for deep-sea oceanographical work. The equipment also provides for echo sounding. The latest 'world span' wireless apparatus is in part a gift from the Marconi Co. towards the work of the ship. Dr. T. J. Hart will be in charge of the work at sea until the ship reaches Cape Town. With him will be Mr. R. Clarke (who will take over on leaving the Cape), and Mr. R. I. Currie; Lieutenant-Commander A. F. MacFie will be in executive command. 